\title{
Człowiek - natura - sacrum. O tajemnicy istnienia na wybranych przykładach pol- skiej literatury wieku XIX i XX
}

\author{
Bartłomiej Borek
}

https://orcid.org/0000-0002-7503-8703

W artykule poddano interpretacji wybrane dzieła Adama Mickiewicza, Bolesława Prusa, Stanisława Przybyszewskiego, Bronisławy Ostrowskiej, Kazimiery Iłłakowiczówny i (kontekstowo) Jana Kasprowicza. Swoistej re-lektury dokonano z wykorzystaniem triady człowiek - natura - sacrum, warunkującej postrzeganie sakralizowanego świata. Taki punkt wyjścia pozwolił na przedstawienie niejasnych, kosmicznych i tajemniczych proweniencji antropomorfizowanych bohaterów (na przykład natury czy wojny), a także podkreślenie ich psychicznych i fizycznych metamorfoz. W analizie wykorzystano mitoznawstwo porównawcze i krytykę ekumeniczną, stanowiące punkt wyjścia do docierania do głębokich warstw semantycznych tekstów, co pozwoliło na nowe odczytania.

Słowa kluczowe: człowiek, natura, sacrum, kosmos, tajemnica, metamorfoza, poezja

Czy sacrum jest wynikiem powiązania człowieka i natury, czy może - przeciwnie - ta koherencja jest rezultatem obecności sacrum? Niełatwo jednoznacznie odpowiedzieć na to pytanie, ale jedno można potraktować jako pewnik - kiedy człowiek łączy się z naturą, a natura sprzęga się z człowiekiem, obecne staje się

BARTŁOMIEJ BOREK, magister filologii polskiej, doktorant literaturoznawstwa w Zakładzie Literatury Pozytywizmu i Młodej Polski UMCS w Lublinie; adres do korespondencji: ul. Zachodnia 2/19, 20-620 Lublin; e-mail: borek.bartlomiej@wp.pl 
także sacrum, czyli to, co święte, niejasne, metafizyczne. Natura zaczyna być traktowana jak żywa istota, a jej aktywność przyjmuje charakter wolicjonalny i coraz bliższa jest bytowi ludzkiemu - jednostce świadomej, kreującej rzeczywistość na własnych zasadach. Takiego oglądu natury należy upatrywać już w starożytności, kiedy spisany został bodaj najsłynniejszy akadyjski epos o losach Gilgamesza - władcy miasta Uruk. Nie bez powodu powołuję się na ów mit: to w nim prawdopodobnie po raz pierwszy zastosowano zabieg antropomorfizacji w stosunku do tego, co nie było człowiekiem, ale sugerowało możliwości trwania na podobnych zasadach. Ożywienie, nadające ludzkie cechy bytom proweniencji różnej od ludzkiej, stało się w antyku grecko-rzymskim atrakcyjnym popisem retorycznym, o czym zdają się świadczyć nie tylko największe dzieła tych czasów, ale i podrzędne (często wtórne) epigramaty.

Starożytni, odkrywając naturę człowieka, zapragnęli zrozumieć, w jaki sposób na Ziemi pojawiał się człowiek. Poza wyjaśnieniami stricte biologicznymi doszukiwano się początku ludzkości także w gwiazdach. Warto odnotować, że choć teorii było wiele, niektóre zdawały się atrakcyjniejsze od innych pod względem nie tylko poznawczym, ale również estetycznym, co mocno podnosiło rangę bytu, jakim był człowiek. Zaczęto postrzegać jako istotę tajemniczą, połączoną z naturą, całym światem, a nawet kosmosem, w konsekwencji czego również sam wszechświat traktowano na podobnych zasadach, co żywe istoty - jako tak zwanego makroanthroposa ${ }^{2}$. Ewolucję człowieka według takiego myślenia można przedstawić następująco:

\section{CZŁOWIEK $\rightarrow$ KOSMOS $\rightarrow$ CZŁOWIEK $\rightarrow$ NATURA}

Od samego początku funkcjonowania idei „makroanthropos” jej fundamentem był człowiek. Następnie, zapewne w wyniku wpływu katasteryzmu ${ }^{3}-$ czyli idei przeniesienia danej osoby (po śmierci) w formie gwiazd (konstelacji) na firmament niebieski, na przykład w ramach wynagrodzenia za wyrządzone krzywdy

${ }^{2}$ Warto zauważyć, że idea makroanthroposa funkcjonowała niezależnie $\mathrm{w}$ wielu różnych kulturach i regionach świata, od starożytnych Indii poczynając, kończąc zaś na antyku greckorzymskim. W Indiach zawarta została w passusach Rygwedy i Upaniszadach, w antyku grecko-rzymskim rozwijała się od idei katasteryzmu po pisma Hermesa Trismegistosa (hermetyzm).

3 Więcej o katasteryzmie, jego walorach estetycznych i ideologicznych: Marek Herman, Metaforyka astralna w poezji rzymskiej (Kraków: Polska Akademia Umiejętności, 2007). 
czy też w podzięce za zasługi - połączono go z kosmosem, tworząc w ten sposób człowieka kosmicznego. Ale transformacja pojęcia „makroanthropos” trwała nadal. Eklektyczni stoicy, od Posejdonosa po Senekę, podzielając ideę katasteryzmu, przekonywali, że człowiek, a dokładniej - jego dusza - już po umieszczeniu na nocnym niebie, istnieje $\mathrm{w}$ "sublunarnych regionach kosmosu” 4 , czyniąc kosmos żywym, wskutek czego miał on znamionować rozumowy element eteru. W ten sposób eter mógł ożywiać wszystkie składowe przestrzeni. To rozpoznanie pozwala przejść do kolejnych elementów przedstawionego wcześniej grafu, tym razem ponownie do człowieka (jednak już nie tego przedkosmicznego, a istoty naznaczonej pierwiastkiem kosmicznym), ale i natury. Człowiek kosmiczny, przywdziewając ludzką powłokę (materię), ponownie zszedł na Ziemię i zapragnął odkryć istotę sacrum. Dlatego też makroanthropos, będąc duchowym bytem w ciele, znajduje się - o czym wspomina jedna ze staroindyjskich Upaniszad ${ }^{5}$ - „w aureoli słońca”, czyli doświadczeniu pełni, co doprowadza go do zetknięcia z prawdą o istnieniu.

W tym momencie makroanthropos zyskuje przekonanie o „Ja-Wszystkim”. Na drodze aktu sugerującego coś na wzór platońskiej anamnezy przypomina sobie swoje przedludzkie wcielenie, umieszczenie duszy w świecie i świadomości, bez którego nic nie mogłoby trwać. Pobudzona jaźń popycha go do pozostawienia w mikro- i makrokosmosie swego atmicznego pierwiastka. W ten sposób łączy on byt z Bytem, dokonuje duchowej transgresji rzeczywistości postrzegalnej w świat idei. Świat, który tak dokładnie obserwuje, zaczyna postrzegać jako emanację własnego "Ja". Makroanthropos staje się w chwili wtajemniczenia autentycznie wszystkim, gdyż cały świat jest nim i w nim. Kosmiczny makroanthropos wskazuje zatem na personalizację świata rzeczywistego, będącego jednocześnie żywą istotą, i stąd właśnie w przedstawionym grafie umieszczenia wymaga natura - postrzegana jako byt żywy, świadomy, kosmiczny.

\footnotetext{
${ }^{4}$ Andrzej Wypustek, „Motyw powrotu duszy do eteru w greckich epigramach nagrobnych”, Acta Universitatis Wratislaviensis 2010, z. 30: 151.

${ }^{5}$ Por. Brihadaranjaka 5.5.2.
} 


\section{Makroanthropos. Człowieka - natura - sacrum}

Po tak nakreślonym wstępie warto przejść do wybranych przykładów literackich i wskazać na powiązanie człowieka i natury z sacrum, kosmosem, tajemnicą i wszystkim tym, co wydawać się może skrajnie irracjonalne. Wśród pisarzy wykorzystujących zdekonstruowaną powyżej wizję rzeczywistości wymienić należy choćby Adama Mickiewicza, Bolesława Prusa ${ }^{6}$, Jana Kasprowicza, Stanisława Przybyszewskiego, Bronisławę Ostrowską czy Kazimierę Iłłakowiczównę. Oczywiście lista mogłaby być znacznie dłuższa, jednak w szkicu ograniczę się tylko do najbardziej reprezentatywnych, modelowych przykładów.

\section{Proza}

Prawdopodobnie po raz pierwszy koncepcję makroanthroposa w badaniach literaturoznawczych przypomniał Zdzisław Kępiński ${ }^{7}$, poddając analizie twórczość autora Pana Tadeusza. Odczytał on postać Konrada w kontekście człowieka kosmicznego, rozszyfrowując $\mathrm{w}$ ten sposób znaczenie jednego z bardziej osobliwych cytatów pomieszczonych w Wielkiej Improwizacji :

Ja mistrz!

Ja mistrz wyciągam dłonie!

Wyciągam aż w niebiosa i kładę me dłonie

Na gwiazdach jak na szklannych harmoniki kręgach ${ }^{8}$.

Analizując ów passus, badacz stwierdził: „Człowiek stojący na ziemi, a sięgający gwiazd osiąga wielkość całego świata [...]. W tym momencie rozpoznajemy doskonale nam znany schemat przedstawiający nagiego mężczyznę z ramionami

${ }^{6} \mathrm{O}$ „człowieku kosmicznym” i różnych kreacjach tego fenomenu wspominam w artykule oddanym do druku w monografii zbiorowej poświęconej Bolesławowi Prusowi w 120. rocznicę rozpoczęcia druku jego Najogólniejszych ideałów życiowych. Rozważania zatytułowałem „Księżyc nieśmiało wyjrzał ku ziemi, a spostrzegłszy na skraju nieba rąbek czerwonych blasków, pomyślał’... Rozważania Bolesława Prusa o księżycu.

${ }^{7}$ Por. Zdzisław Kępiński, Mickiewicz hermetyczny (Warszawa: PWN, 1980), 204.

${ }^{8}$ Por. Adam Mickiewicz, „Dziady, cz. III”, w: tenże, Utwory dramatyczne, t. III, oprac. Stanisław Pigoń (Warszawa: Czytelnik, 1983), 155. 
uniesionymi i rozpostartymi szeroko (czasem też z rozstawionymi nogami) i wpisanego w koło lub w czworobok. Jest to człowiek kosmiczny (makroanthropos)"9. Nie ma powodu sądzić, że Kępiński nie ma racji, a nawet więcej: na podstawie tych spostrzeżeń warto poprowadzić dalszą interpretację wizerunku Konrada.

Istniejąc na granicy światów, Mickiewiczowski buntownik staje się kreacją niejednoznaczną ontologicznie. Jest zdolny do tworzenia przestrzeni (sięga przecież gwiazd ${ }^{10}$ ), w których bytuje, a właściwie jest ich częścią. Słuszny okazuje się zatem wniosek, że włada on także własną duchowością, potrafi złączyć się z kosmicznym uniwersum, odczuwając jego obecność w duszy.

Dzieje Konrada są modelowym przykładem nieustającego spełniania warunków na drodze do stania się prawdziwym makroanthroposem. Poza wspomnianym już dosięgnięciem gwiazd, rodzi się on na nowo z Gustawa ${ }^{11}$ - romantycznego kochanka, zmieniając się w Konrada - poruszyciela fasad rzeczywistości, $\mathrm{w}$ następstwie czego otrzymuje upragnioną gnosis.

Nie należy zapominać, że Konrad, dzieląc się sobą z kosmosem, nieprzerwanie tkwi ciałem w więziennej celi, która wprawdzie ogranicza aktywność bohatera, jednak nie wpływa negatywnie na jego aktywizm. Płynie z tego prosty wniosek: kolejny z warunków bycia makroanthroposem nie okazuje się dla Konrada niemożliwy do spełnienia.

Mogłoby się wydawać, że Konrad-makroanthropos nie wypełni wymogu bycia rozczłonkowanym, jak to miało miejsce w narracji o Zagreusie-Dionizosie. Nic bardziej mylnego - ów romantyczny kreator rzeczywistości dotknięty jest rozczłonkowaniem w nader subtelnym (dlatego zapewne niedostrzeżonym do tej pory przez literaturoznawców) aspekcie psychicznym:

Myśli moje! gwiazdy moje!

Czucia moje! wichry moje! ${ }^{12}$

\footnotetext{
${ }^{9}$ Kępiński, Mickiewicz hermetyczny, 204.

${ }^{10}$ Stojąc na fundamencie Ziemi, sięga gwiazd, w rezultacie czego staje się człowiekiem kosmicznym - „Człowiekiem Drogi Mlecznej” (tak Tadeusz Miciński określa bohatera poematu Niedokonany). Zaciera w ten sposób granicę dzielącą rzeczywistość postrzegalną od świata idei.

${ }^{11}$ Zmiana imienia przywodzi na myśl postać Dionizosa, który przed śmiercią nazywany był Zagreusem. Zagreus został rozczłonkowany przez rozwścieczonych tytanów. Z ocalałego serca Atena ożywiła go w postaci bardziej znanego kulturze Dionizosa.

${ }^{12}$ Mickiewicz, „Dziady”, 56.
} 
Kosmiczny umysł Konrada, umieszczony w tej fantasmagorycznej czasoprzestrzeni, tworzy świat i żywioły, staje się podstawą bytu. W ten sposób - w duchowości ujętej w kosmicznych bezbrzeżach - ujawnia się obecność dziejącego się właśnie aktu indywiduacji: uwolnienia jaźni i pozostawienia jej w onirycznej rzeczywistości.

W odmienny sposób problem koherencji człowieka i natury ujął Bolesław Prus w noweli $Z$ legend dawnego Egiptu. Przypomnijmy sobie scenę, kiedy to przerażony wizją przyszłych rządów Horus (mężczyzna dowiedział się właśnie o szybko postępującej chorobie dziada Ramzesa), zmierzając do swej komnaty zostaje ukąszony i zatruty (!) przez pająka, którego użądlenie zostało początkowo błędnie zidentyfikowane jako niegroźny atak miododajnej pszczoły:

Nagle syknął z bólu.

- Co ci jest, Horusie?

- Pszczoła ukąsiła mnie w nogę - odparł pobladły książę.

Dworzanin przy zielonawym blasku księżyca obejrzał mu nogę ${ }^{13}$.

Zielone światło księżyca wydaje się nie tylko efektownym elementem egipskiego krajobrazu, ale też nośnikiem kluczowych znaczeń - zapowiada śmierć, jego barwa ewokuje truciznę ${ }^{14}$. Z czasem zaczyna to rozumieć także następca tronu faraonów. Pozostały mu czas odmierzyć ma księżyc:

- Prędkoż to może się stać?... Powiedz prawdę...

- Nim księżyc schowa się za tę oto palmę...

- Ach, tak! $!^{15}$

${ }^{13}$ Bolesław Prus, „Z legend dawnego Egiptu”, w: tenże, Pisma, t. IX, red. Ignacy Chrzanowski, Zygmunt Szweykowski (Warszawa: Wydawnictwo Gebethnera i Wolffa, 1935), 243.

${ }^{14}$ Por. Jolanta Sawicka, „Symbolika lunarna w średniowiecznej poezji liturgicznej”, Pamiętnik Literacki 93, nr 3 (2002): 6. Literaturoznawczyni na pierwszych stronach szkicu przytacza bogatą bibliografię poświęconą symbolice księżyca, nie ograniczając się przy tym wyłącznie do sugerowanego w tytule artykułu okresu średniowiecza. Inna badaczka, Aldona Senczkowska, przypomina słowa Antoniego Kępińskiego, piszącego o ziemskim satelicie, że niekiedy symbolizował on także melancholię, „Zapewne z powodu jego związków z nocą, melancholicznym światłem i wiarą w lunatyzm” - Aldona Senczkowska, „»Lunarna osobowość« Juliusza Słowackiego. Zarys problemu," Litteraria 2012, z. 39: 61. Więcej na ten temat w: Antoni Kępiński, Melancholia (Wydawnictwo Literackie, Kraków 2001), 280. Wracając do Sawickiej: przekonuje ona także, iż Księżyc - w przeciwieństwie do Słońca - był „złym okiem Boga". Szerzej o tym problemie w: Mircea Eliade, Traktat o historii religii, tłum. Jan WieruszKowalski (Warszawa: Aletheia, 1966), 131.

${ }^{15}$ Prus, „Z legend”, 246. 
Horus, oszołomiony i sparaliżowany wyrokiem czasu, przeżywa najtragiczniejszy moment swego istnienia. Świadomy niemożności wcielenia w życie edyktów znoszących w kraju tyranię, z każdą minutą czuje się przygniatany przez czas, którego percypowanym sensorycznie odpowiednikiem staje się sięgający liści palmy ${ }^{16}$ księżyc. Warto zauważyć, że niezwykłość tej temporalnej przenośni nie wynika - jak mogłoby się wydawać - wyłącznie z jej plastyczności: sens metaforycznej konstrukcji jest znacznie głębszy. Prus, konstruując obraz zmienności świata, prawdopodobnie sięgnął do symboliki makroanthroposa (nie zapominajmy, że nie tylko autor Lalki uległ fascynacji teorią Maxa Müllera o odrodzeniu humanistycznym w Indiach ${ }^{17}$ ). Idea ta, jak już wspominaliśmy, opiera się na przekonaniu, że wszechświat to byt organiczny, żywy, mogący w odpowiedni sposób oddziaływać na ziemską rzeczywistość. Ale, co znaczące, w opisie Prusa nie dzieje się to, co miało miejsce choćby w XXXII wierszu Księgi ubogich Jana Kasprowicza, gdzie opadające z drzewa liście stanowiły „obrazowy ekwiwalent odrywania się od continuum życia" ${ }^{18}$. W noweli $Z$ legend dawnego Egiptu funkcja odmierzania czasu przypadła księżycowi. Jego modelowo pragmatyczna cecha została powiązana z metafizycznym przejściem do krainy cieni. Czas wyznaczany przez ruch księżyca uległ jakościowej ewolucji, został usakralizowany, w rezultacie czego zaczął konotować wartości transcendentne. Święty tempus „dotknął pierwszych liści” ${ }^{19}$ palmy i zaczął metaforyczny bieg w kierunku Horusa.

${ }^{16}$ Wybór akurat tego drzewa wydaje się znaczący. Babilończycy, doświadczając wielokrotnie ogromnej siły palm, stawiających opór wszelkim warunkom pogodowym (suszy, nawałnicom, burzom), uważali je za drzewa łaski, a nawet bóstwa natury. Grecy i Rzymianie również dostrzegali w nich przejaw boskości, łącząc „świetlane drzewa” z Heliosem. Prawdopodobnie z tej właśnie przyczyny zaczęto wiązać roślinę z feniksem - mitycznym ptakiem, który odradzał się z płomieni, siedząc $\mathrm{w}$ gnieździe usytuowanym w koronie palmy. Poza tym gałązki palmowe symbolizowały nieśmiertelność - to cecha znacząca dla naszej interpretacji. Por. Dorothea Forstner, Świat symboliki chrześcijańskiej, tłum. i oprac. Wanda Zakrzewska, Paweł Pachciarek, Ryszard Turzyński (Warszawa: PAX, 1990), 175. Warto też wspomnieć, że palma daktylowa, o której zapewne pisał Prus, jest też symbolem męczeństwa, duszy, wzniosłości, proroctwa (!), sprawiedliwości, a w starożytnym Egipcie uważano ją za alegorię roku (dwunastu miesięcy). Twierdzono, że drzewo to wraz z nadejściem nowego miesiąca rodzi nowy liść. Co ciekawe, liście palmy były poświęcone Hermesowi, który odprowadza dusze zmarłych do miejsca przeznaczeń. Por. „Palma”, w: Władysław Kopaliński, Słownik symboli (Warszawa: Wiedza Powszechna, 1990), 298-300.

${ }^{17}$ Por. Jan Tuczyński, Motywy indyjskie w literaturze polskiej (Warszawa: PWN, 1981), 132.

18 Wiesław Olkusz, „Orientalizm w poezji doby pozytywizmu”, Pamiętnik Literacki 82, nr 2 (1991): 37.

${ }^{19}$ Prus, „Z legend”, 247. 
Nie bez powodu wspomniana została też metafora biegu. Do głosu dochodzi tu antropomorfizacja: czas staje się Człowiekiem-makroanthroposem - ma ręce, którymi dotyka palmowych liści, a także nogi, przybliżające go do wykonania wyroku. Traktując czas jako żywy byt, jesteśmy zmuszeni uznać jego istnienie na wszechzwiązku zjawisk, zdarzeń i rzeczy ${ }^{20}$. Musimy też zauważyć, że wszystkie składowe tak ujętego wszechświata spaja właśnie relacja czasowa. Czas, wpływając na życie Horusa, zmienia też losy całego Egiptu ${ }^{21}$. Przyjmuje funkcję boskiego pośrednika - działającego między ziemską a niebiańską dziedziną - obwieszczającego wyroki nie własne, a Absolutu.

Dosyć osobliwy projekt postrzegania natury świata zaprezentował w jednym ze swych poematów prozą Stanisław Przybyszewski. W utworze Androgyne ${ }^{22}$, którego akcja rozgrywa się na granicy jawy i snu, wprzągł w oniryczną wizję psychokosmicznego ścierania się sił dobra i zła także rozpoznania makroantropiczne. Jego bohater w zetknięciu z naturą, innym człowiekiem (kobietą) oraz kosmosem, bierze udział w przypomnieniu ${ }^{23}$ sobie o ukrytych w człowieku kosmicznych ideach:

Szedł cichy i wielki, bo dusza jego ukazała mu swe najskrytsze głębie, pozwoliła mu czytać swe najtajniejsze runy - i szedł potężny, bo niósł słońce w sobie. Szedł coraz wyżej stromym szlakiem, ale szedł lekko, jakby go coś niosło, aż wreszcie stanął na szczycie wysokiej góry. Spojrzał w dół - w kotlinie u stóp jego to rozkołysane morze dachów, dyszące świetlistą

${ }^{20}$ Por. Marek Łagosz, Realność czasu (Wrocław: Wydawnictwo Uniwersytetu Wrocławskiego, 2007), 33.

${ }^{21}$ Por. Ireneusz Opacki, „Gra symetrii (»Z legend dawnego Egiptu« Bolesława Prusa)”, w: Nowela, opowiadanie, gawęda. Interpretacje małych form narracyjnych, red. Kazimierz Bartoszyński, Maria Jasińska-Wojtkowska, Stefan Sawicki (Warszawa: PWN, 1979), 153.

${ }^{22} \mathrm{O}$ poemacie Androgyne i obecnym w nim micie androgynii napisano już wiele - por. choćby: Wojciech Gutowski, Nagie dusze i maski. O młodopolskich mitach miłości (Kraków: Wydawnictwo Literackie, 1992); Maria Podraza-Kwiatkowska, „Salome i Androgyne. Mizoginizm a emancypacja”, w: taż, Symbolizm i symbolika w poezji Młodej Polski (Kraków: Wydawnictwo Literackie, 1994); Gabriela Matuszek, „Melancholik, mistyk, narcystyczny kochanek, samotny "homo dolorosus«”, w: Stanisław Przybyszewski, Poematy proza (Kraków: Wydawnictwo Literackie, 2003).

${ }^{23}$ Dostrzegalne są tu inspiracje platonizmem. Bohater Przybyszewskiego zdaje się przypominać postaci naznaczone ideą anamnezy, o której pisał w swych dialogach Platon. Więcej o anamnezie w: Richard Schaeffler, „Przypomnienie/anamneza”, tłum. Paweł Pachciarek, w: Leksykon religii, red. Franz König, Hans Waldenfels (Warszawa: Verbinum, 1997), 369-370; Robert Mielhorski, „Światło anamnezy. O utworze Zbigniewa Herberta Pan Cogito myśli o powrocie do rodzinnego miasta”, Filo Sofija 14, nr 27 (2014): 159. 
łuną światła - to miasto jego. A w dali poza miastem pasmo gór wygięte, połamane, zjeżone gdyby szeregi gdzieś spoza widnokręgu napływających bałwanów morskich, porosłe lasami kasztanów. Zielone góry kasztanów, wysadzone białymi kiściami kwiecia - och, jak płonęły gromniczne świece kwiecia na zielonym adamaszku, co zda się z nieba spływał w dół ku miastu! Naraz wezbrało się serce jego nieznaną potęgą, wrósł w niebo, wyciągnął ramiona; dziki krzyk rwał mu się z serca, by słońce, które niósł w piersiach, pokazać całemu światu; czuł, że rozlewa światłość wokól siebie, czul, że się wznosi ponad wszechżycie - czuł się wniebowziętym $^{24}$. [podkr. własne - B.B]

Podkreślone fragmenty wykazują zbieżność z Mickiewiczowskim Konradem-makroanthroposem. Zauważmy, że bohater-artysta (drugi człon tego określenia kieruje uwagę na twórczą moc tej jednostki), tak jak Konrad ulega metamorfozie: zaczyna rządzić, władać naturą. W geście wzniesienia rąk ku niebu łączy się z kosmicznym uniwersum, a przede wszystkim odnajduje w sobie pierwiastek makroanthroposa, gdy zaczyna rozumieć, że w swej piersi nosi „słońce” - symbol boskości.

Stojąc na szczycie góry i doświadczając przemiany w sferze psychicznej, staje się również inicjatorem zewnętrznej ewolucji świata. Zyskując wiedzę o poddaniu i przypisaniu swego "Ja" otaczającej go faunie i florze, w konsekutywnym akcie zmienia za pomocą słownego medium (w akcie performacji) ontologiczność świata postrzegalnego. W ten sposób natura zyskuje jakości jubilerskie ${ }^{25} \mathrm{i}$ architektoniczne ${ }^{26}$. Kasztanowce ze świata roślin, na skutek jubilerskiej metafory wysadzenia kryształami (kwiatami), ulegają transpozycji do dziedziny geologii. Dzieje się coś tajemniczego i niewyobrażalnego dla zwykłego człowieka. Bohater Przybyszewskiego ma własną wizję świata, która zmierza do niego zza linii horyzontu.

${ }^{24}$ Stanisław Przybyszewski, Androgyne (Kraków: Drukarnia Wydawnicza im. W. L. Anczyca, 1900), 23.

${ }^{25}$ Por. Maria Podraza-Kwiatkowska, „Sugestia”, w: taż, Symbolika i symbolizm w poezji Młodej Polski, 242.

${ }^{26} \mathrm{O}$ symbolice architektonicznej por.: Wojciech Gutowski, „Burzyciel świątyń i budowniczy nadgwiezdnych miast. O symbolice architektonicznej w twórczości Tadeusza Micińskiego”, w: tenże, Pasje wyobraźni. Szkice o literaturze romantyzmu i Młodej Polski (Toruń: Towarzystwo Naukowe w Toruniu, 1991); Maria Podraza-Kwiatkowska, „Symbol architektoniczny. Zejście w głąb. Martwa natura”, w: taż, Symbolika i symbolizm w poezji Młodej Polski, 167-184; Eugeniusz Czaplejewicz, „Architektoniczne wizje Prusa (państwa, człowieka i literatury)”, w: Dziewiętnastowieczność. Z poetyk polskich i rosyjskich XIX wieku. Prace poświęcone X Międzynarodowemu Kongresowi Slawistów w Sofii, t. LXXII, red. Eugeniusz Czaplejewicz, Wincenty Grajewski (Wrocław: Zakład Narodowy im. Ossolińskich, 1988). 
Widzi więcej niż pozwalają mu na to ziemskie zmysły. Patrząc na świat postrzegalny i poprzez niego, siegga granic przestrzeni naznaczonych przez sacrum, wpływając w ten sposób na zlanie przeciwieństw. Świat doczesny łączy z transcendentnym, urzeczywistniając $\mathrm{w}$ ten sposób ideę scalenia przeciwieńst ${ }^{27}$. W tym przełomowym momencie w sercu ${ }^{28}$ mężczyzny dała o sobie znać potęga człowieka kosmicznego, psychokosmiczna samoświadomość jedności bytu w duszy człowieka. Rzeczywistość konsystencjalna może istnieć dzięki jego sercu, zaś sam dzierżyciel boskiej iskry pragnie oznajmić całemu światu swą wielkość poprzez ekstatyczny krzyk. Pobudzona jaźń mężczyzny ma się przyczynić do wszechświatowego, solarnego misterium oświecenia, zaś jemu samemu pozwolić odczuć moment przekroczenia granic świata - doświadczyć tajemnicy drugiej strony.

Warto odnotować, że bohater Androgyne ulega temu, co André Breton określił mianem „introspekcji w głębie obszaru mentalnego, zawrotnego poczucia uczestnictwa w burzach Kosmosu i namiętności tworzących jedno"29. Kosmiczny artysta, pobudzając swą psychikę do dokonania transgresji w świecie wewnętrznym „Ja”, ale także na zewnątrz - w świecie postrzegalnym i idealistycznym, z którym przecież się zlewa - ulega procesowi indywiduacji ${ }^{30}$ i rozbudzenia jaźni. Jest to niezwykła chwila deifikacji własnego jestestwa, przebóstwienia w formę solarną. Co ciekawe, podobnie, choć nie tak efektownie, został opisany bezimienny bohater poematu Wśród gwiazd autorstwa Wincentego Korab-Brzozowskiego. Mężczyzna dąży do aktu „przesłonecznienia”, przechodząc metamorfozę składającą się z kilku etapów - odrzucenie ziemskiego ciała; przyobleczenie skrzydeł, z których bił niebieskawy blask elektryczności; zyskanie umiejętności telepatycznej rozmowy z naturą; doświadczenie jedności stworzenia. Mimo że bohater nader usilnie starał się o osiągnięcie pełni, nie zostało dane odkryć mu w sobie tej

${ }^{27} \mathrm{O}$ idei coincidentia oppositorum, którą Mikołaj z Kuzy określił mianem „najmniej niedoskonałej definicji Boga”, napisano już wiele, por. np. Jarosław Frontczak, „Poszukiwanie paradygmatu”, Sztuka i Filozofia 1996, nr 11: 57 i 60; Artur Przybysławski, Coincidentia oppositorum (Gdańsk: słowo/obraz terytoria, 2004).

${ }^{28}$ Widać tu zaskakujące podobieństwo do historii Zagreusa-Dionizosa (starożytna Grecja) czy Puruszy (starożytne Indie), opisanego w Mundace 2.1.4.

${ }^{29}$ André Breton, cyt. za: Krystyna Janicka, Światopoglad surrealizmu (Warszawa: Wydawnictwo Artystyczne i Filmowe 1985), 228. Na potrzeby wkomponowania cytatu w zdanie pozwoliłem sobie na zmianę końcówek fleksyjnych niektórych wyrazów, nie przekształcając oczywiście myśli Bretona.

${ }^{30}$ Por. Leszek Kolankiewicz, Carl Gustav Jung - wędrowiec Wschodu: Podróż na Wschód (Warszawa: Pusty Obłok, 1989), 12. 
skrzętnie skrywanej przez świat tajemnicy. Uczestnicząc w mysterium tremendum et fascinosum ${ }^{31}$, w którym człowiek poddany sile pierwotnego sacrum odczuwa wewnętrzny lęk - jednocześnie ulegając sile oczarowania nim - stał się uczestnikiem niejasnej dla niego poznawczo transformacji. Jego ulegające zmianie ciało miało stać się przestrzenią ścierających się kosmicznych potęg, objawiając jakości metafizyczne ${ }^{32}$, jednak droga protagonisty została naznaczona upadkiem.

W kontekście omawianego poematu Przybyszewskiego warto wyeksplikować jeszcze jedną ważną składową, która wpływa na obrany tu sposób interpretacji dzieła. Mam na myśli motyw pierwotnej androgynii, obecności kobiety w akcie przebóstwienia. Bohater Androgyne doświadcza przekroczenia wszelkich granic rzeczywistości na skutek zafascynowania kobiecością:

I w tej samej chwili — w godzinie wielkiego cudu przekształcił mu się cały świat. Wszystkie formy i kształty zlały mu się w jedną giętką, wiotką linię; całe potopy barw, promieni światła spłynęły w jeden ciemny, gorący blask; ocean dźwięków, drgnień, ruchów, gięć i fal rozkwitł jednym pysznym kwieciem pieśni - pieśni, którą była ona - ona jedyna ${ }^{33}$.

Właśnie zjednoczenie z przeciwnym mu płciowo bytem dokonać ma tej niesłychanie efektownej psychokosmicznej transgresji, w której urzeczywistni się i objawi światu - na drodze hierofanii - wielkość makroanthroposa:

I na toż go jego ziemia wydała, na toż rysowała i żłobiła swoje kształty w jego duszy, by się jej postać w nią zlać mogła, jak w odwiecznie przygotowaną formę? [...] I na toż rozjęczała się cała jego ziemia nieskończenie smutną pieśnią, rozdźwiękły dzwony pochmurną zadumą, na ugorach wiatr zawodził w takt poszumu rozkołysanych łanów pszenicznych - by każde drgnienie, każdy ruch jej wiotkich członków, każde zagięcie jej kształtów mogło spłynąć z odwieczną harmonią jego duszy? ${ }^{34}$.

Gabriela Matuszek, omawiając poemat, zwróciła szczególną uwagę na samotność bohatera w momencie przeżywania „godziny cudu”. Kreacja idealnego

${ }^{31}$ Por. Rudolf Otto, Świętość: elementy irracjonalne w pojęciu bóstwa i ich stosunek do elementów racjonalnych (Wrocław: Thesaurus Press, 1993), 40.

${ }^{32}$ Por. Agata Skała, „W poszukiwaniu prawdy o człowieku. »Diokles« Henryka Sienkiewicza”, Estetyka i Krytyka 2009/2010, z. 17/18: 244.

${ }_{33}^{3}$ Przybyszewski, Androgyne, 22.

${ }^{34}$ Tamże. 
oblicza kobiecości zinterpretowana została przez nią, jako „gigantyczna narcystyczna psychomachia" ${ }^{35}$. Moment całowania narcyzów potraktowała Matuszek na zasadzie inicjującego wyłonienie się miłosnego ideału $\mathrm{z}$ wnętrza podmiotu - objaw jego autoerotyzmu. Narcyz w tej interpretacji to oczywiście nie tylko kwiat symbolizujący egocentryzm, ale także asumpt do poszukiwań psychologicznych, w szczególności deszyfracji pojęć z zakresu introspekcji, autoerotyzmu oraz samowystarczalności ${ }^{36}$. Zwłaszcza introspekcja - poprzedzająca moment indywiduacji - czyli badanie wnętrza samego siebie, zdaje się być koniecznym składnikiem narcystycznej osobowości. Narcyz potrzebuje jednak określonego narzędzia samooglądu i samopoznania, czegoś na kształt gładkiej tafli mitycznego strumienia - lustra własnego „Ja”.

Badaczka oczywiście szuka tego lustra i odnajduje je w kobiecie oraz pojęciu ideału $^{37}$. Według Matuszek wyłaniająca się z wyobraźni bohatera kobieta to krystaliczna projekcja, odbicie bohatera-Narcyza. Bohater poematu, przekonuje dalej badaczka, niejednokrotnie stwierdza, że owa idealna kochanka jest właściwie nim samym ${ }^{38}$. Narcystyczny podmiot, kontemplujący samego siebie i wytworzony przez siebie obraz idealnej kochanki, reprezentuje megalomanię typową dla bohaterów Przybyszewskiego ${ }^{39}$, dodaje Matuszek. I tak jak mitologiczny Narcyz, który nie może odwzajemnić miłości do własnego oblicza, umiera z tęsknoty, tak pragnienie dosięgnięcia bezprzedmiotowego obiektu, czegoś, co jest paradoksalnie nim samym, będzie przyczyną śmierci bohatera poematu Przybyszewskiego ${ }^{40}$.

Wydaje się, że koncepcja Matuszek, choć oczywiście poparta odpowiednią literaturą, wpływa na pominięcie sakralnej warstwy znaczeniowej dzieła, gdyż sam aspekt cielesności, obecny przecież $\mathrm{w}$ utworze - z czym nie zamierzam polemizować - należałoby powiązać $\mathrm{z}$ eschatologią. Zatem tę erotyczną ekscytację narcystyczną można postrzegać jako panerotyczne misterium wtajemniczenia $\mathrm{w}$ idee początku - „narodzin” (!) świata.

${ }^{35}$ Gabriela Matuszek, Stanisław Przybyszewski - pisarz nowoczesny. Eseje i proza - próba monografii (Kraków: Universitas, 2008), 209.

${ }^{36}$ Por. „Narcyz”, w: Kopaliński, Stownik symboli, 249-250.

${ }^{37}$ Por. „Lustro”, w: Kopaliński, Słownik symboli, 206-209.

${ }^{38}$ Por. Matuszek, Stanisław Przybyszewski, 212.

${ }^{39}$ Por. taż, „Demony Przybyszewskiego, czyli o szatanie wczesnej nowoczesności”, Stan Rzeczy 1, nr 1 (2011): 124-125.

${ }^{40}$ Por. Matuszek, Stanisław Przybyszewski, 212 i 217. 
Koncepcja Matuszek zdaje się mieć także lukę w schematycznej interpretacji postaci mitycznego Narcyza, który przyjmuje tu wartości czysto ludzkie, bez odpowiedniego wyartykułowania jakości metafizycznych. Swego czasu, pisząc o Narcyzie, dowodziłem, że jedna ze starożytnych narracji przedstawia go w zupełnie innej odsłonie ${ }^{41}$. Pauzaniasz, opisując losy Narcyza, wplótł do miłosnych dziejów postać siostry bliźniaczki. Szybko rozwijająca się akcja dzieła ukazuje moment śmierci ukochanej Narcyza, w następstwie czego przenosi naszą uwagę na aspekt jego samotności. Nie mogąc poradzić sobie ze stratą, spogląda w leśne źródło i doświadcza wtajemniczenia w byt. Paradoksalnie dla Narcyza nie jest ważne doświadczenie miłości - można zaryzykować taką hipotezę, gdyż dając wodzie swe odbicie, kreuje on na tafli obraz siostry sprzed śmierci. W ten sposób może doświadczyć doskonałego stanu sprzed podziału płci - i sprzed narodzin. Możliwe, że motyw akwatyczny pełni funkcję jeszcze ważniejszą: leśne źródełko może symbolizować wrota łona, w skutek czego głębiny Styksu - z którego to przecież źródła wybiła sadzawka - przemieniają się w płodowe wody mitycznego praembrionu. Jednak ta historia także kończy się klęską bohatera, gdyż nie jest mu dane doświadczenie stanu rzeczy sprzed przybrania cielesnej formy. Dlatego wody nie koją, nie łagodzą bólu, stają się wyłącznie „wodami śmierci” ${ }^{42}$.

Erotyczny aspekt dziejów bohatera Androgyne zdaje się odnosić do kosmicznego wymiaru androginiczności, a jeżeli zaanektować do niego pierwiastki narcystyczne, wydaje się dodatkowo implikować wymiar eschatologiczny dzieła i - jak trafnie zauważa Wojciech Gutowski, powołując się na Gilberta Duranda - świadczy o „współsubstancjalności kosmosu i mikrokosmosu” ${ }^{43}$. Słuszne w obranej przez Matuszek somatycznej interpretacji dzieła zdaje się przekonanie, że obecność cielesności konotuje przeżycie na skraju erotyki i eschatologii, nie skupia się wyłącznie na fizyczności bytu. Bliskie takiemu odczytaniu dzieła są nie tylko fragmenty poematu: „[...] nie miał jej przy sobie, była nim, rozlała się w nim”44, ale

${ }^{41}$ Por. Bartłomiej Borek, „»Idzie miłość do mnie, gdy wiszę nagi wśród szyderczych zwierciadeł«. O tajemnicy miłości własnej w „Niedokonanym” Tadeusza Micińskiego”, w: Oblicza miłości. Studia literaturoznawcze, red. Krzysztof Bałękowski, Kamil Maciąg (Lublin: Tygiel, 2016), 65-81.

${ }^{42}$ Por. Tomasz Sikora, EUOI. Studia z symbolizmu i metaforyzacji katoptrycznej (Kraków: Nomos, 2004), 199.

${ }^{43}$ Wojciech Gutowski, „Pokusy nicości i tajemnic Pełni. Młodopolskie obrazy eschatologii”, w: tenże, $Z$ próżni nieba ku religii życia. Motywy chrześcijańskie w literaturze Młodej Polski (Kraków: Wydawnictwo Literackie, 2001), 353.

${ }^{44}$ Przybyszewski, Androgyne, 48. 
też zawołania podmiotu $Z$ cyklu wigilii: „Pani. Ty we mnie. Ja Tobą, Tyś mną”45, czy: „Nie potrzebuję ciebie, [...] ale Ciebie we mnie” ${ }^{46}$.

Interesujący obraz zespolenia człowieka $\mathrm{z}$ otaczającą rzeczywistością przedstawił Przybyszewski w późniejszym dziele - Tyrteusz (1915). Tym razem człowiek ustępuje nieco miejsca społeczno-politycznemu aspektowi wojny - traktowanej jako świadomy byt. Ponownie bezimienny - co dodatkowo wzmaga tajemniczość - bohater rozważa istotę zbrojnych konfliktów, czyniąc jednocześnie ważne rozpoznania natury gnoseologicznej. Po pierwsze, Ziemię nazywa Matką ${ }^{47}$. Opisując ten zakorzeniony w kulturze topos, mówi:

Święty i dostojny gospodarz: Matka-Ziemia - otworzył na oścież wrota swych olbrzymich śpichlerzy, by móc ten niesłychany plon przebogatego żniwa pomieścić. Suto zastawione stoły dla skrzętnych żniwiarzy, a u wejścia oczekuje kusząca przodownica, odświętnie przybrana „Śmierć" i wywija kosą, ustrojoną w kwiaty i różnobarwne wstęgi i zaprasza nieprzeliczone zastępy uznojonych gości w hojny i w wszelakie bogactwa przeobfity dom gospodarza: MatkiZiemi, Rodzicielki i Grobu ${ }^{48}$.

Sugestywny obraz śmierci wzbudza w podmiocie wątpliwości, przez co zaczyna on rozmawiać z własnym „Ja” o istocie wojny. Porównuje ją do wybuchu wulkanu czy trzęsienia ziemi, w wyniku czego zmierza do przekonania samego siebie - ponieważ nie jest jeszcze gotowy przyjąć do świadomości - że winy za wszelkie zło w świecie ponosi właśnie natura, Matka-Ziemia, która w jego ustach

${ }^{45}$ Stanisław Przybyszewski, „Z cyklu wigilii”, w: tenże, Poematy proza (Kraków: Wydawnictwo Literackie, 2003), 204.

${ }^{46}$ Tamże, 205.

${ }^{47}$ Matka-Ziemia, ukazana w utworze Przybyszewskiego dość wyraźnie zdaje się ewokować mit Wielkiej Matki. Wielka-Matka, reprezentując siły natury i człowieka (te drugie ze względu na proces antropomorfizacji, której ulega) uosabia jednocześnie więź między mikro- a makrokosmosem. Ziemia staje się miejscem licznych przeobrażeń $\mathrm{w}$ warstwie nie tylko znaczeniowej, ale także psychicznej bohatera utworu. Por. Tomasz Tomasik, „Spotkanie z Wielką Matką: sztuka paleolityczna w twórczości Wisławy Szymborskiej i Zbigniewa Herberta”, Pamiętnik Literacki 103, nr 1 (2012): 142. Warto przywołać także słowa Jürgena Moltmanna, który pisał: „Świat jako całość ma postać matki. Wielka Matka zrodziła i wykarmiła wszystkie żywe istoty. Ona jest kosmicznym prawzorem człowieka. Sięgający czasów sprzed Ariów, indyjscy Dżainiści postrzegali wszechświat jako kolosalnego człowieka - Wielką Matkę". Jürgen Moltmann, Bóg w stworzeniu, tłum. Zbigniew Danielewicz (Kraków: Znak, 1995), 490-491.

${ }^{48}$ Stanisław Przybyszewski, Tyrteusz ( $z$ cyklu „Wojna”) (Wiedeń: Wydawnictwo Naczelnego Komitetu Narodowego, 1915), 14. 
staje się „Trucicielką ludzkości”. Jednak prowadzony przez niego monolog w poszukiwaniu prawdy o bycie doprowadza go do zaskakującego rozpoznania, degradującego wartość ludzkości, ale także do współczucia i pełni zrozumienia dla czynów żywej Ziemi:

Jakżeby można pojąć, dla czego by ziemia - ta wielka potężna ziemia - miała spokojnie znosić, by jakieś natrętne robactwo, które się ludzkością nazywa, miało ustawicznie jej skórę pługami rozraniać, pod nią się wgrzebywać, bezustannie ją przewiercać, w bolesnych torturach krew z niej dobywać, urągać jej tunelami, mostami, kopalniami - niepojętem mu się zdawało, dlaczego miałaby się ziemia wobec tego natrętnego chciwego, złośliwego plugastwa obojętnie zachowywać $^{49}$.

Ziemia, karmiąca swych mieszkańców, dokonuje wielkich poświęceń - tak jak człowiek pragnie wznosić się, pokonywać słabości i imponować. Okazuje się, że ta ambitna istota pragnie pokonać samego Boga, nie wspominając już nawet o Szatanie, który śmiejąc się z jej poczynań, uświadamia sobie, że to właśnie Ziemia doprowadziła do większej makabry wśród ludzkiego istnienia. Rodząc owoc swego łona, dzieli się ona (może nawet w akcie zemsty?) ze światem zatrutym - na skutek niszczenia przez ludzkość - pokarmem, przyczyniając się w ten sposób do wszechświatowego oszołomienia, delirium, niezrozumiałego amoku, w którym ludzkość wyniszcza się wzajemnie.

Myślący nad istotą świata i wojny mężczyzna staje się świadkiem i uczestnikiem edeniczno-infernalnych wizji. W apokaliptycznej przestrzeni, gdzie pojawia się też śmierć przystrojona w kwiaty, wybrzmiewa donośny głos grzmotu: „Nie ma śmierci - śmierć istnieć przestała" ${ }^{\text {. }}$. Możliwe, że mężczyzna słyszy słowa, które przekazało św. Janowi na Patmos siedem grzmotów, nakazujących prorokowi zapieczętować wieść, ale jej nie zapisywać (Ap.10:5). Czyżby historia zmierzała do końca? Jeśli tak, to prawdopodobnie tylko historia niewiedzy, dzieje ludzkiego zaślepienia. Przed mężczyzną otwierają się nowe przestrzenie i postępująca możliwość poznania istoty wojny:

Szerzej i szerzej roztwierały się jego oczy, by pojąc ogrom jakiegoś niepojętego Cudu: Różnice stanów przestały istnieć, bo wszystko brata się z sobą - zaciekłe walki partyjne, które do niedawna gorączkowały umysły, ustały, jakby zaklęte różdżką czarowną - cały ten olbrzymi

\footnotetext{
${ }^{49}$ Tamże, 16.

${ }^{50}$ Przybyszewski, Tyrteusz, 19.
} 
tłum, rozrywany na cząstki i cząsteczki najróżnorodniejszymi, wręcz sobie przeciwnymi i wrogimi interesami, ten sam tłum, który pozostawał z sobą w wiecznej niezgodzie, rozterce, kłótni, nieustających swarach, teraz stał się jedną zwartą masą, jednym potężnym organizmem i w którego żyły jedno tylko serce tą samą krew wlewa. Nie widział żadnego nakazu, bo każdy jeden i ten sam nakaz w sercu swym nosi [...]. Stało się coś niepojętego: Jednostka nie żyje w państwie, ale stała się państwem - nie podlega rządowi, ale jest rządem - nie! Fałszywie pomyślał: jednostka, jako taka przestała istnieć, jest tylko jedna jednostka, w której wszystkie inne doszczętnie się zlały: Naród cały! [...] patrzył ze zdumieniem na Naród-Jednię, rozpacz nim szarpała i zawołał wielkim głosem: O Ludu, mój Ludu! Czem byś mógł być, gdyby i dla Ciebie nadeszła ta święta chwila, w której byś się poczuł nierozerwalną Jednią: jednym mózgiem, jednem sercem i wolną jedną!? ${ }^{51}$.

Wojna czyni świat jednością. Nikną wszystkie granice i schematy obecne w ludzkim systemie wartości. Przestają istnieć podziały klasowe, polityczne, zaś wojna kształtuje z ludzkości kosmiczną strukturę - wszechorganizm. Na mocy tego zrozumienia podmiot działań twórczych czyni także rozpoznanie gnostyckie, iż ludzka dusza nienawidzi pokoju, gdyż wtedy „drzemie”"52, zaś ciało staje się dla niej więzieniem. Dusza leniwieje, w skutek czego zapomina o swym przedludzkim bycie, dlatego wojnę, której istotę ciągle zgłębia, bohater określa mianem „gniewu Duszy wszechświata" ${ }^{53}$. Kosmos ma duszę, żyje - tak samo jak Ziemia czy naród postrzegany w kategoriach urbanistycznych ${ }^{54}$ - a jego bronią jest nic innego, jak właśnie wojna, nosząca znamiona ożywionego bytu.

${ }^{51}$ Tamże, 21-23.

${ }^{52}$ Niewątpliwie słuszne są też skojarzenia z ideą ujętą w Genesis $z$ ducha czy Lilli Wenedzie, w których to Juliusz Słowacki przekonywał, że „zleniowiony” duch musi zostać pokonany, upaść pod naporem ducha aktywnego.

${ }^{53}$ Przybyszewski, Tyrteusz, 26.

${ }^{54}$ W koncepcji wynikającej z Dialogów Platona trzy składowe: kosmos, polis (miasto) i człowiek pozostają ze sobą w ścisłej koherencji. Polis projektowane jest na założeniach makroanthroposa, człowiek na zasadach mikropolis, zaś kosmos ujmowany $\mathrm{w}$ kategoriach żywego makropolis, ufundowanego na prawach. U Platona, dla którego świat doświadczalny empirycznie był tylko odbiciem świata idei, odpowiednia wydaje się koncepcja analogiczności także w odniesieniu do Ziemi i Kosmosu. Autor Dialogów, mówiąc o człowieku, myśli równocześnie o polis i kosmosie, zaś państwo postrzega jako odbicie powszechnych praw rządzących kosmosem. Por. Platon, Timajos, Kritias albo Atlantyk, tłum. Paweł Siwek (Warszawa: PWN, 1986), 41. 


\section{Poezja}

Zmierzając do końca analiz, warto w celu zarysowania przeciwwagi dla wniosków wyartykułowanych na podstawie prozy przyjrzeć się wyimkom z lirycznej twórczości kobiet - Bronisławy Ostrowskiej i Kazimiery Iłłakowiczówny. Wymienione poetki zawarły w strofach swych wierszy najpiękniejsze i najsubtelniejsze odcienie makroantropicznej zasady istnienia świata - powołały się na psychologiczną strukturą bytu. Pierwsza z nich w swym bodaj największym - ale zaskakująco lapidarnym - dziele wyraziła tajemnicę świata w słowach:
Magdaleno, ciszo polna,
Magdaleno, ciszo leśna,
Która zlewasz mi pod nogi
Miłosierny balsam drogi
I ocierasz włosy swemi
Stopy, pylne kurzem ziemi,
Z wszechboleści - bezboleśna,
$\mathrm{Z}$ wszechniewoli - siostro wolna,
Dzięki tobie - ciszo leśna...
Dzięki tobie - ciszo polna... ${ }^{55}$

Chyba wszyscy interpretatorzy poezji Ostrowskiej napisali choćby kilka słów o tym liryku. Warto przywołać choćby opinię Stefana Lichańskiego, który uważał go za przejaw „najgłębszej tożsamości trzech członów relacji: Ja - natura - Bóg” ${ }^{56}$, czy Macieja Krassowskiego, określającego tekst mianem „arcydzieła polskiej liryki międzywojennej" ${ }^{57}$. Mimo skondensowanej formy wiersz został obudowany filozoficznymi i biblijnymi kontekstami. Dzieje Magdaleny implikują monistyczną

${ }^{55}$ Bronisława Ostrowska, „Magdaleno, ciszo polna”, w: taż, Antologia (Warszawa: Hachette, 2012), 124.

${ }^{56}$ Stefan Lichański, „Spójnia ślubnego pierścienia”, w: tenże, Cienie i profile. Studia i szkice literackie (Warszawa: PIW, 1967), 368.

${ }^{57}$ Maciej Krassowski, „O poezji Bronisławy Ostrowskiej. Wstęp”, w: Bronisława Ostrowska, Poezje wybrane (Warszawa: Ludowa Spółdzielnia Wydawnicza, 1976), 15. 
interpretację dzieła. Jej losy nie są egzemplifikacją dualności świata ujętego w kategoriach ducha i materii, wręcz przeciwnie, stanowią przejaw konieczności ich zespolenia, harmonijnego ujednolicenia. Dlatego właśnie Magdalena (człowiek) łączy się z ciszą polną (naturą), by w akcie unii osiągnąć z nią jedność. Ów aspekt organizuje jednocześnie sakralny (panteistyczny) wymiar dzieła.

Warto odnotować, że ujęta w dziesięciu wersach cisza ewokuje jakości metafizyczne. To właśnie stan bezwzględnego wyciszenia przybliża do wsłuchania się w głos Transcendencji, poświadczający obecność pankosmicznego uniwersum w ziemskim świecie. Jak pisał Licheński, w tym momencie dochodzi do pojednania Boga, człowieka i natury. Wszystko przenika wszystko, natura zyskuje wartości ludzkie i boskie - ulega spirytualizacji, człowiek zaś, chcąc uczestniczyć w tym misterium, wnika w naturę swą psyche w sposób niemożliwy do ogarnięcia rozumem, nie wspominając choćby słowem o ciele, jakby bariera somy w ogóle nie istniała. Jak to wyjaśnić? Należy podkreślić, że oświecenie ludzkiej istoty jest eksterioryzowane na świat natury. Magdalena pozostawia uwolnioną jaźń w przyrodzie, w wyniku czego staje się jej częścią, a może nawet więcej - czyniąc naturę rozumną i dokonując jej przebóstwienia, samą siebie czyni przyrodą, dlatego też nie potrzebując ciała. Nie musi o nim nawet wspominać. Od tej pory natura staje się świątynią, do której dostęp ma tylko człowiek przestrzegający wiecznych praw i prawd natury.

Podobnie w poezji Kazimiery Iłłakowiczówny. Jednym z takich obrazów jest liryk Fontanna, w którym proces myślenia przypisany został żywiołowi - wodzie. Natura, jak przekonywał swego czasu Maurycy Mochnacki, żyje, gdyż myśli, a „myśleć jest to żyć” 58 - natura „myśli naszą myślą i sama siebie naszym pojmuje rozumieniem" 59 . Zbigniew Baran, badacz poezji autorki Rusałek, analizując wspomniany utwór, napisał: „Liryczny obraz wody myślącej w tekście poetki jest bliski poglądom wielkich polskich romantyków (Mickiewicza, Słowackiego, Norwida) o duchowej jedności natury i człowieka, wywodzącym się z ewolucyjnej idei Wielkiego Łańcucha Bytów, która była popularna i znana w epoce romantyzmu" ${ }^{60}$.

${ }^{58}$ Por. Maurycy Mochnacki, O literaturze polskiej w wieku dziewiętnastym, oprac. Henryk Życzyński (Kraków: Krakowska Spółka Wydawnicza, 1923), 25.

${ }^{59}$ Tamże, 26.

${ }^{60}$ Zbigniew Baran, Artystyczne i kulturowe pierwiastki poezji Kazimiery Iłłakowiczówny w procesie edukacji literackiej dzieci i młodzieży (Wałbrzych: Wydawnictwo Wałbrzyskiej Wyższej Szkoły Zarządzania i Przedsiębiorczości, 2014), 77. 
W innym liryku, Mowie lipy, poetka ponownie użycza głosu naturze, tym razem pozwalając jej nawet wyartykułować myśli:

Co mówi dorodne drzewo, ciężka od kwiatu lipa?

„Wydarłam dojrzałą mądrość z czarnego uścisku polipa;

wróg mój pozostał w ziemi, z niego ma piękność i siła.

Dajcie rozkwitnąć słońcu, będę je na rękach nosiła!

Z czarnego zamknięcia w łupinie mniejszej niż ziarno ostu

Wdarłam się w tęsknotę przeznaczenia, weszłam w męczeństwo wzrostu,

przetrwałam trwogę suszy, przeżyłam szarpanie burzy...

Dajcie mi tylko przestwór - gałęzie w niebie zanurzę!"61.

Bohaterem wiersza jest drzewo, ale drzewo mimo swej typowości niezwykłe. Tytułowa lipa myśli, planuje, mówi, ma pragnienia, które wyraża w słowach: „Dajcie mi tylko przestwór - gałęzie w niebie zanurzę!”. Myśląca natura pragnie zespolenia z kosmosem, jej marzeniem jest zanurzyć się (zlać) w niebo i dosięgnąć słońca, które potem będzie nosić w swych „rękach”(!). Także ona czuje siłę, która dozwoliłaby jej stać się nosicielką najjaśniejszej z gwiazd - Słońca. Jednak tym, co charakteryzuje mądrą lipę, jest także świadomość przemijania. Mówiąc o przekleństwie wzrostu, ta przedstawicielka świata przyrody (zapewne kuzynka Prusowskiej palmy) przypomina nam o nieprzerwanym upływie czasu. Prawdopodobnie wyłącznie ona jest tak przerażająco świadoma istnienia rzeczywistości bez możliwości uwolnienia jaźni. I choć autorka Pokusy zapewne nie inspirowała się podczas pisania utworu motywem lasu, wyraziście eksponowanym w Młodej Polsce i stanowiącym jeden $\mathrm{z}$ ważniejszych dla epoki symboli ${ }^{62}$, to z przekonaniem można stwierdzić, że nader umiejętnie ukazała sacrum, drzemiące od wieków w naturze.

${ }^{61}$ Kazimiera Iłłakowiczówna, „Mowa lipy”, w: taż, Wiersze zebrane, t. 1 (Warszawa: PIW, 1971), 483.

${ }^{62}$ Por. Wojciech Gutowski, „Tajemnice młodopolskich lasów. O kluczowym symbolu poetyckim”, w: tenże, Mit - Eros - Sacrum. Sytuacje młodopolskie (Kraków: Homini, 1999), 97-112. 


\section{Podsumowanie}

Poczynione tu refleksje sugerują możliwość re-lektury znanych nam dzieł, dozwalając na re-/dekonstrukcję spetryfikowanych już rozpoznań. Człowiek, natura i sacrum to pojęcia, których obecne w literaturze zespolenie należy moim zdaniem do najbardziej wyjątkowych i estetycznie najatrakcyjniejszych prób literackich w naszej literaturze. Do tej pory niewyartykułowane - bądź jedynie wspomniane - antropocentryczne jakości natury w omówionych w szkicu utworach, podkreśliły ich sakralny wymiar. Wprzęgnięcie w tok analiz idei makroanthroposa nie tylko wskazało na metafizyczny charakter natury i człowieka, ale podkreśliło też konieczność kolejnych analiz, skupiających się na poszukiwaniu możliwych źródeł, z których czerpali polscy pisarze XIX i XX wieku, gdyż kultura śródziemnomorska to stanowczo za mało. Postrzeganie natury we wspomnianej formie pozwala na traktowanie jej w kategoriach świadomego bohatera, konstruktora rzeczywistości, autonomicznego uczestnika dziania się, zaś człowieka jako byt jeszcze bardziej niejasny i niemożliwy do poznania rozumowego.

\section{Bibliografia}

Baran, Zbigniew. Artystyczne i kulturowe pierwiastki poezji Kazimiery Iłłakowiczówny w procesie edukacji literackiej dzieci i młodzieży. Wałbrzych: Wydawnictwo Wałbrzyskiej Wyższej Szkoły Zarządzania i Przedsiębiorczości, 2014.

Borek, Bartłomiej. „»Idzie miłość do mnie, gdy wiszę nagi wśród szyderczych zwierciadeł«. O tajemnicy miłości własnej w „Niedokonanym” Tadeusza Micińskiego”. W: Oblicza miłości. Studia literaturoznawcze, red. Krzysztof Bałękowski, Kamil Maciąg, 65-81. Lublin: Tygiel, 2016.

Czaplejewicz, Eugeniusz. „Architektoniczne wizje Prusa (państwa, człowieka i literatury)”. W: Dziewiętnastowieczność. Z poetyk polskich i rosyjskich XIX wieku. Prace poświęcone $X$ Międzynarodowemu Kongresowi Slawistów w Sofii, t. 77, red. Eugeniusz Czaplejewicz, Wincenty Grajewski, 375-402. Wrocław: Zakład Narodowy im. Ossolińskich, 1988.

Eliade, Mircea. Traktat o historii religii. Tłum. Jan Wierusz-Kowalski. Warszawa: Aletheia, 1966.

Falk, Maryla. Mit psychologiczny w starożytnych Indiach. Tłum. Ireneusz Kania. Kraków: Universitas, 2011.

Forstner, Dorothea. Świat symboliki chrześcijańskiej. Tłum. i oprac. Wanda Zakrzewska, Paweł Pachciarek, Ryszard Turzyński. Warszawa: PAX, 1990. 
Frontczak, Jarosław. „Poszukiwanie paradygmatu”. Sztuka i Filozofia 1996, nr 11: 52-65.

Gutowski, Wojciech. „Burzyciel świątyń i budowniczy nadgwiezdnych miast. O symbolice architektonicznej w twórczości Tadeusza Micińskiego". W: tenże, Pasje wyobraźni. Szkice o literaturze romantyzmu i Młodej Polski, 113-147. Toruń: Towarzystwo Naukowe w Toruniu, 1991.

Gutowski, Wojciech. Nagie dusze i maski. O młodopolskich mitach miłości. Kraków: Wydawnictwo Literackie, 1992.

Gutowski, Wojciech. „Pokusy nicości i tajemnic Pełni. Młodopolskie obrazy eschatologii”. W: tenże, Z próżni nieba ku religii życia. Motywy chrześcijańskie w literaturze Młodej Polski, 316-369. Kraków: Wydawnictwo Literackie, 2001.

Gutowski, Wojciech. Mit - Eros - Sacrum. Sytuacje młodopolskie. Kraków: Homini, 1999.

Herman, Marek. Metaforyka astralna w poezji rzymskiej. Kraków: Polska Akademia Umiejętności, 2007.

Iłłakowiczówna, Kazimiera. Wiersze zebrane, t. 1, Warszawa: PIW, 1971.

Janicka, Krystyna. Światopogląd surrealizmu. Warszawa: Wydawnictwo Artystyczne i Filmowe, 1985.

Kępiński, Antoni. Melancholia. Kraków: Wydawnictwo Literackie, 2001.

Kępiński, Zdzisław. Mickiewicz hermetyczny. Warszawa: PWN, 1980.

Kolankiewicz, Leszek. „Carl Gustaw Jung - wędrowiec Wschodu”. W: Carl Gustav Jung: Podróż na Wschód, red. Leszek Kolankiewicz, 5-29. Warszawa: Pusty Obłok, 1989.

Kopaliński, Władysław. Słownik symboli. Warszawa: Wiedza Powszechna, 1990.

Krassowski, Maciej. „O poezji Bronisławy Ostrowskiej”. W: Bronisława Ostrowska, Poezje wybrane, 5-20. Warszawa: Ludowa Spółdzielnia Wydawnicza, 1976.

Lichański, Stefan. „Spójnia ślubnego pierścienia”. W: tenże, Cienie i profile. Studia i szkice literackie, 367-399. Warszawa: PIW, 1967.

Łagosz, Marek. Realność czasu. Wrocław: Wydawnictwo Uniwersytetu Wrocławskiego, 2007.

Matuszek, Gabriela. „Demony Przybyszewskiego, czyli o szatanie wczesnej nowoczesności”. Stan Rzeczy 1, nr 1 (2011): 117-130.

Matuszek, Gabriela. „Melancholik, mistyk, narcystyczny kochanek, samotny »homo dolorosus«”. W: Stanisław Przybyszewski. Poematy prozą, 5-37. Kraków: Wydawnictwo Literackie, 2003.

Matuszek, Gabriela. Stanisław Przybyszewski - pisarz nowoczesny. Eseje i proza - próba monografii. Kraków: Universitas, 2008.

Mickiewicz, Adam. „Dziady, cz. III”. W: tenże, Utwory dramatyczne, t. 3, oprac. Stanisław Pigoń, 123-256. Warszawa: Czytelnik, 1983.

Mielhorski, Robert. „Światło anamnezy. O utworze Zbigniewa Herberta »Pan Cogito myśli o powrocie do rodzinnego miasta «". Filo-Sofija 14, nr 27 (2014): 159-184.

Mochnacki, Maurycy. O literaturze polskiej w wieku dziewiętnastym. Kraków: Krakowska Spółka Wydawnicza, 1923. 
Olkusz, Wiesław. „Orientalizm w poezji doby pozytywizmu”. Pamiętnik Literacki 82, nr 2 (1991): 17-59.

Opacki, Ireneusz. „Gra symetrii. (»Z legend dawnego Egiptu« Bolesława Prusa)”. W: Nowela, opowiadanie, gawęda. Interpretacje małych form narracyjnych, red. Kazimierz Bartoszyński, Maria Jasińska-Wojtkowska, Stefan Sawicki, 131-155. Warszawa: PWN, 1979.

Ostrowska, Bronisława. Antologia. Warszawa: Hachette, 2012.

Otto, Rudolf. Świętość: elementy irracjonalne w pojęciu bóstwa i ich stosunek do elementów racjonalnych. Wrocław: Thesaurus Press, 1993.

Platon. Timajos, Kritias albo Atlantyk. Tłum. Paweł Siwek. Warszawa: PWN, 1986.

Podraza-Kwiatkowska, Maria. Symbolizm i symbolika w poezji Młodej Polski: teoria i praktyka. Kraków: Wydawnictwo Literackie, 1975.

Prus, Bolesław. „Z legend dawnego Egiptu”. W: tenże. Pisma, t. 9, red. Ignacy Chrzanowski, Zygmunt Szweykowski, 241-248. Warszawa: Wydawnictwo Gebethnera i Wolffa, 1935.

Przybysławski, Artur. Coincidentia oppositorum. Gdańsk: słowo/obraz terytoria, 2004.

Przybyszewski, Stanisław. Androgyne. Kraków: Drukarnia Wydawnicza im. W. L. Anczyca, 1900.

Przybyszewski, Stanisław. Tyrteusz ( $z$ cyklu „Wojna”). Wiedeń: Wydawnictwo Naczelnego Komitetu Narodowego, 1915.

Przybyszewski, Stanisław. Z cyklu wigilii. W: tenże. Poematy prozą, 169-206. Kraków: Wydawnictwo Literackie, 2003.

Sawicka, Jolanta. „Symbolika lunarna w średniowiecznej poezji liturgicznej”. Pamiętnik Literacki 93, nr 3 (2002): 5-35.

Schaeffler, Robert. „Przypomnienie/anamneza”. Tłum. Paweł Pachciarek. W: Leksykon religii, red. Franz König, Hans Waldenfels, 369-370. Warszawa: Verbinum, 1997.

Senczkowska, Aldona. „»Lunarna osobowość« Juliusza Słowackiego. Zarys problemu”. Litteraria 2012, nr 39: 59-74.

Sikora, Tomasz. EUOI. Studia z symbolizmu i metaforyzacji katoptrycznej. Kraków: Nomos, 2004.

Skała, Agata. „W poszukiwaniu prawdy o człowieku. »Diokles« Henryka Sienkiewicza”. Estetyka i Krytyka, 2009-2010, nr 17/18: 237-247.

Tomasik, Tomasz. „Spotkanie z Wielką Matką: sztuka paleolityczna w twórczości Wisławy Szymborskiej i Zbigniewa Herberta”. Pamiętnik Literacki 103, nr 1 (2012): 129-145.

Tuczyński, Jan. Motywy indyjskie w literaturze polskiej. Warszawa: PWN, 1981.

Wypustek, Andrzej. „Motyw powrotu duszy do eteru w greckich epigramach nagrobnych”. Acta Universitatis Wratislaviensis 2010, nr 30: 145-156. 


\section{Summary}

\section{Human - nature - sacrum. The mistery of the existence in selected examples of Polish literature of the XIX and XX century}

The article is an interpretation of the literary works by Adam Mickiewicz, Bolesław Prus, Stanisław Przybyszewski, Bronisława Ostrowska, Kazimiera Iłłakowiczówna and (contextually) Jan Kasprowicz. The proposed rereading of these texts involves the triad human - nature - sacrum, which determines the perception of a sacralized literary world. Such perspective enables to show the vague, cosmic and arcane provenances of anthropomorphic characters (human, nature, war etc.) in the selected works and allows to underline their psychological and physical metamorphoses. Comparative mythology and ecumenical criticism were used as a starting point for the analysis, which paved the way for the deeper semantic layers of the texts, resulting in new interpretations.

Keywords: human, nature, sacrum, mystery, metamorphosis, cosmos, poetry

\section{Zusammenfassung}

\section{Mensch - Natur - Sacrum. Über das Geheimnis der Existenz an ausgewählten Beispielen aus der polnischen Literatur des 19. und 20. Jahrhunderts}

Im Artikel werden ausgewählte Gedichte von Adam Mickiewicz, Bolesław Prus, Stanisław Przybyszewski, Bronislawa Ostrowska, Kazimiera Iłłakowiczówna und (kontextbezogen) Jan Kasprowicz interpretiert. Die Relektüre wurde unter Anwendung der Triade Mensch - Natur - Sacrum vollzogen, die die Betrachtung der sakralisierten Welt bedingt. Ein solcher Ausgangspunkt gestattete die Schilderung von verwirrter, kosmischer und geheimnisvoller Provenienz der anthropomorphisierten Figuren (z. B. Natur oder Krieg) und die Hervorhebung ihrer psychischen und physischen Metamorphosen. Bei der Analyse wurde auch vergleichende Mythenforschung und ökumenische Kritik herangezogen, die den Ausgangspunkt für die Erkundung der tieferen semantischen Schichten der Texte bilden, was zu ihrer neuen Auslegung führt.

Schlüsselworte: Mensch, Natur, Sacrum, Geheimnis, Metamorphose, Kosmos, Dichtung Information about Author:

BARTŁOMIEJ BOREK, Master of Polish philology, PhD candidate in literary studies at Department of Positivism and Young Poland Literatures, Maria Curie-Skłodowska University in Lublin; address for correspondence: Zachodnia 2/19, 20-620 Lublin; e-mail: borek.bartlomiej@wp.pl

(cc) BY-NC-ND 